Article

\title{
Intercultural Dating at Predominantly White Universities in the United States: The Maintenance and Crossing of Group Borders
}

\section{Micere Keels * and Keshia Harris}

Department of Comparative Human Development, The University of Chicago, 5730 S. Woodlawn Avenue, Chicago, IL 60637, USA; E-Mail: keshia1@uchicago.edu

* Author to whom correspondence should be addressed; E-Mail: micere@uchicago.edu; Tel.: +1-773-702-1368; Fax: +1-773-702-3971.

Received: 7 February 2014; in revised form: 29 April 2014 / Accepted: 19 June 2014 /

Published: 27 June 2014

\begin{abstract}
The increased representation of minority students on the campuses of predominantly White universities in the United States presents increased opportunities for intercultural contact. Studying dating experiences across racial and ethnic lines has been used to determine the existence of a post-racial America. While most previous research has examined general racial/ethnic and gender differences in intercultural college dating experiences, this study analyzes precollege and college-going friendship diversity and skin tone as factors accounting for romantic distance between racial/ethnic groups among a recent cohort of college students. Hierarchical linear modeling analyses were conducted on a 4-year longitudinal sample of 2804 undergraduate students from 24 colleges and universities. Results confirm that White students continue to be the group most likely to engage in intragroup dating relationships, Latino/a students were the most likely to date interculturally, and that Black men were significantly more likely to date interculturally than Black women. For Black students there were significant within group differences in intercultural dating based on skin tone.
\end{abstract}

Keywords: intercultural dating; college students; friendship diversity; skin tone; United States

\section{Introduction}

Many who claim a post-racial America point to the rise in intercultural marriage, particularly Black-White marriage, as proof that Americans are becoming color-blind, or at least matter-of-fact 
about color. We use the inclusive term intercultural because both interracial and interethnic relationships are examined in the present study. The rise in intercultural marriage is seen as a barometer of the strength of racial/ethnic boundaries and social distance [1,2]. Intermarriage is believed to extend cross group interaction beyond the couple in the relationship, and create connections between the social networks to which each member of the couple belong. Furthermore, the children of intercultural marriages are believed to extend the break down of barriers because they often identify with multiple racial/ethnic groups. Finally, at the level of society, as the fraction of intercultural marriages increase, the salience of racial/ethnic boundaries decreases.

The positive association between education and intercultural marriage is a hotly debated issue. Education is expected to increase the likelihood of intercultural romantic relationships and eventually marriage [3]. However, the evidence from intercultural marriages shows that even among college-educated Americans significant and substantial racial/ethnic-by-gender gaps remain [2,4]. Nonetheless, prior analyses of intercultural marriages lump together all currently married Americans, the majority of whom attended postsecondary institutions that were significantly less racially/ethnically diverse than colleges and universities of today. To remedy this limitation of previous analyses and to telegraph the future of intercultural marriage among college-educated Americans, we examine data on the romantic relationships of a recent cohort of college students.

Contrary to the post-racial rhetoric, a few recent studies have found high levels of dating segregation among college students [3]. This is unexpected because college students meet all of the criteria required for meaningful racial/ethnic mixing-young in age, of a post-modern cohort, high educational status, frequent cross-race/ethnicity contact, and are outside of immediate family sanctioning [5,6]. Furthermore, college campuses are depicted as places where individuals of many different racial/ethnic, cultural, and religious stripes come together and learn to move beyond assumptions about the 'other', and learn to appreciate people as individuals [7]. However, there is evidence that on college campuses, despite their lofty goals, individuals of different racial/ethnic groups come together and share space (live, eat, attend classes, and participate in extracurricular activities), but often maintain separate social lives [8,9]. The results presented in this study further our understanding of the extent to which Black, Latino/a, and White college students go beyond simply sharing social space to sharing romantic lives.

\section{Background}

\subsection{Intercultural Marriage in the United States}

Examining intercultural marriages, marriage across racial lines (Black-White) and marriage across ethnic lines (White-Latino/a, Black-Latino/a) allows us to explore the roles of phenotypic and cultural factors in determining social distance between groups [10,11]. Literature measuring social distance among various racial/ethnic groups has found that non-Black minorities hold higher social positions than Blacks but lower social positions than Whites [12]. Due to the history of enslavement and intense race relations in the U.S., the hierarchical racial/ethnic divide may be upheld most strongly between Blacks and Whites. Thus it is likely that intercultural relationships are approached differently between Blacks, non-Blacks, and Whites. 
Despite the societal significance of intermarriage, and despite substantial increases in intermarriage, as a fraction of all marriages, intercultural marriage remains low: an increase from $3 \%$ of all marriages in 1980 to $8 \%$ in 2010 [13]. However, intercultural marriage among this generation of newlyweds has become substantial, substantial for all except Black women. For example, among White men entering into an intercultural marriage, 46\% married a Latina, 27\% married an Asian woman, and only 7\% married a Black woman; among White women entering into an intercultural marriage, 51\% married a Latino, 20\% married a Black man, and only 9\% married an Asian man. Wilkins, Chan, and Kaiser [14] suggest that these racial/ethnic-by-gender gaps in intermarriage stem from racial/ethnic stereotypes about femininity and masculinity that shape perceived attractiveness.

Adding education to our understanding of intercultural marriage allows us to develop a more nuanced picture of how mutual socializing experiences can reduce cross-group interpersonal barriers [15]. The effect of education on intercultural marriage differs by race/ethnicity, such that Black-Latina and White-Latina gaps in intermarriage are largest among college-educated women $[2,4]$. This is because Latinas significantly increase their likelihood of intermarriage with increasing education, whereas Black and White women show essentially no change in intermarriage with increasing education [2]. Based on the 2006-2010 American Community Survey, approximately 23.4\%, 10.2\%, and 5.4\% of married high school educated Latina, Black, and White women were in an intercultural marriage, compared to $43.5 \%, 10.9 \%$, and $5.2 \%$ of married college-educated Latina, Black, and White women. These findings indicate that, for marriage, schooling plays a substantial role in reducing the Latino/a-White social distance, but has little effect on Black-White social distance [16]. Such low rates of intermarriage among college-educated Black women further constrain their marriage opportunities, which are already limited by the relative decline in college-educated Black men [17].

Intercultural dating is a salient and high stakes issue for Latina and Black women attending predominantly White institutions (PWIs) [12]. Nationally, the college student population is about $65 \%$ female for Black students and $60 \%$ female for Latino/a students, compared to $55 \%$ female for White students [18]. Intercultural dating therefore, determines the extent to which Latina and Black female students can alleviate the within race/ethnicity demographic dating squeeze.

\subsection{Black Students and Intercultural Dating}

For over four decades, researchers have been reporting that Black female college students express serious concern and even "panic" regarding the small pool of Black men on college campuses $[19,20]$. The campus gender imbalance has been identified as a negative factor in the quantity and quality of college-going Black women's romantic experiences [21-23]. Schoepflin [8] found that Black women attending PWIs had a limited dating landscape, due to the limited availability of Black men and to the reluctance of White men to date Black women. Currently, romantic relationship homophyly restricts Black female college students' ability to circumvent the sharply unbalanced Black male-female ratio through entering into intercultural relationships [24].

Although, for all racial/ethnic groups, homophyly increases with increasing romantic commitment - from hooking up, to dating, to cohabiting, to marriage, the salience of homophyly varies by one's race/ethnicity-by-gender group membership [24-26]. Among the youngest generations of Americans, racial/ethnic boundaries between Black women and White men are the least likely to be breached [27]. These researchers found that among high school students, Black girls were less likely to 
be romantically involved in schools that were predominantly White, and White boys were less likely to be romantically involved in schools that were 30\%-59\% Black, confirming a low likelihood of intercultural dating between Black women and White men. In contrast, dating among Black male high school students was unaffected by the racial/ethnic composition of the student population. Hence, although several studies have concluded that men (including White men) are willing and likely to date or marry interculturally, the caveat lies in who they are willing to date; among minority women, Latinas are the preferred intercultural dating partner [26,28,29].

\subsection{Latino/a Students and Intercultural Dating}

Proportionally fewer college-age Latino men are enrolling in college than in years past, and degree attainment gaps between Latino men and women are widening [30]. Despite the limited availability of Latino men on college campuses, the within race/ethnicity gender gap may not be a salient issue for Latina women who are open to intercultural dating [24]. One study of college students' intercultural dating behaviors and attitudes found that $90 \%$ of White men and $70 \%$ of Black men viewed Latinas as an attractive intercultural dating partner, whereas $60 \%$ of White men and $52 \%$ of Latino men viewed Black women as an attractive intercultural dating partner [31]. Much of this may be accounted for by the fact that many Latinas match the idealized popular image of American female beauty [26,31,32].

Despite this, intercultural dating is not a given for Latinas, and social network disapproval is a particularly salient issue with regard to their intercultural dating decisions. Latino/a parents play a significant role in establishing dating expectations, and evaluating, and monitoring their daughters' dating partners [33]. In this regard, immigrant generational status is an important factor, as women in recent immigrant families are more likely to have their romantic relationships closely monitored and restricted by their parents [34]. As immigrant generational status increases, Latino/a youth increasingly express disagreement with their parents' preferences for homogenous relationships, and express the desire to marry someone who shares both their cultural background and their level of American acculturation [34,35].

Several factors, more common among younger generations and college-going Latino/a students, positively affect their likelihood of intercultural dating, despite network disapproval and desire for cultural similarity. These factors include: length of time in the U.S., low levels of ethnic identification, high levels of English language acculturation, ethnically diverse social networks, and low ingroup bias and intergroup anxiety [26,32,36,37]. Research on rates of actual intercultural dating is mixed. Some research suggests that Latina women are more likely than men to date interculturally because of their desire for Americanized egalitarian relationships, [34,35]; whereas other studies suggest that Latino men are more likely than women to enter into intercultural relationships to obtain higher economic standing and social approval [36,38,39].

\subsection{White Students and Intercultural Dating}

Prior research has indicated that White Americans tend to date less interculturally than other racial/ethnic groups [26]. Their majority presence on most U.S. college campuses affords them the privilege of numerous intragroup dating options, which is much less available to minority students [24]. Yancey [12] argues that it is about much more than opportunities for intragroup dating, and proposes 
that racial/ethnic mixing, is a group status issue, in which higher status groups are less likely to date lower status groups because affiliation with lower status groups poses challenges to the societal hierarchy that benefits members of higher status groups. Thus, low levels of intercultural dating among White students may be due to a combination of more opportunities for intra versus intercultural dating, uncertainty about disrupting one's present social standing, and inheritance of negative racial/ethnic attitudes and feelings of otherness.

\subsection{Role of Friendship Network Diversity}

The diversity of students' friendship networks is strongly associated with intercultural dating because of increased familiarity with multiple cultural groups, and likelihood of social network approval [38]. Studies investigating intercultural contact have indicated that diverse friendship groups are strongly correlated with more favorable attitudes toward intercultural dating relationships [26,39]. Fischer [40] found an increased likelihood of out-group friendships among college freshman that had previous intercultural relationships, and that racial/ethnic heterogeneity on college campuses increased the likelihood of establishing intercultural friendships, with Latinos in particular. However, racial/ethnic heterogeneity had minimal effect on intercultural friendships with Black students; and, as with intercultural dating, White students were the least likely to report a diverse friendship network. Measurements of both precollege and college-going friendship diversity were included in the present study because high school intercultural interactions are associated with future intercultural interactions, but do not guarantee college-going engagement with a diverse friendship group [7,24,41].

\subsection{Skin Tone and Intercultural Dating}

Attractiveness is culturally determined, and in the U.S. it is heavily influenced by racial stereotypes and European standards of beauty [42]. Particularly for women, fair skin has been considered a desirable feminine characteristic by White, Black, and Latino men. Research shows that self-perceptions as well as judgments about others are often determined by skin tone, suggesting that lighter skin is associated with beauty, privilege, and higher socio economic status, while darker skin is viewed as unintelligent, unattractive, and untrustworthy [11]. Focusing on romantic relationships, skin tone is a predictor of spousal status (i.e., high educational attainment and occupational prestige) for people of color [10]. Associated with this, Latino/a parents in the U.S. encourage their children to avoid relationships with Blacks because of the lower status associated with dark skin [43]. Specifically, Lee [43] found that Columbian, Ecuadorian, and Peruvian American parents preferred that both their male and female children marry White or light skinned individuals because dark skin was associated with perceptions of shame and poverty.

\section{Methods}

Beginning in the fall of 1999, the National Longitudinal Survey of Freshmen (NLSF) sampled freshmen from 28 selective colleges and universities, and surveyed them each spring during their first four years of college [44]. The initial round of data collection was by in-person interviews, and the four waves of follow-up data collection occurred via telephone; virtually all questions were closed-ended. All respondents were freshmen that matriculated immediately after graduating high school. 
Approximately $86 \%$ completed the initial face-to-face interview, and the final wave of data collection was completed by $79 \%$ of the students who completed the initial interview $(76 \%$ of Black, $79 \%$ of Latino/a, and $82 \%$ of White respondents).

The sub-sample used for this paper is limited to students who attended co-educational predominantly White institutions, which reduced the sample to 24 colleges and universities. The analytical sample included 953 Black, 885 Latino/a, and 966 White female and male students. These 24 PWIs had a combined student composition that averaged 70\% White, 7\% Black, and 5\% Latino/a, and a combined gender make-up that was approximately $63 \%$ female among Black students, $57 \%$ female among the Latino/a students, and $51 \%$ female among the White students.

\subsection{Measures}

\subsubsection{Dependent Variables}

Romantic relationships: Students' reports of their sophomore and junior year romantic relationships were examined. In the spring of sophomore and junior year, students reported whether they "have been on any dates since the school year began", whether they "currently have a steady romantic partner", whether any of their dating partners were of a different race/ethnicity, and the race/ethnicity of partners from intercultural relationships. Responses to these questions were used to measure the following outcomes: (1) Whether reported no dates across sophomore and junior year; (2) Whether in a committed relationship, at least once, at time of interview, across sophomore and junior year; (3) Whether dated interculturally, at least once, across sophomore and junior year, of those that reported any dating; (4) Whether committed relationship is intercultural; and (5) Whether dated an Asian, Black, Latino/a, and White individual sophomore or junior year, of those that dated interculturally (four separate variables).

\subsubsection{Independent Variables}

Race/ethnicity and gender: A set of dummy variables indicating students' self-reported race/ethnicity (Black, Latino/a, or White) was created. A dummy variable indicating students' self-reported gender (male or female) was also created.

Racial/ethnic diversity of friendship network: Students were asked about the racial/ethnic composition of their high school and freshman year friendship networks. They were asked, "of your ten closest friends last year/made since coming to college, how many were Black/White/Latino/a". Responses to these questions were used to create two variables: percent of ten closest high school friends that were of the student's same race/ethnicity, and percent of ten closest freshman year friends that were of the student's same race/ethnicity.

Closeness to other racial/ethnic groups: During the fall of freshman year, students reported how close they felt to the men and women of each racial/ethnic group. Specifically, "tell me how close you feel to the people in terms of your ideas and feelings about things. A score of 0 means very distant and a score of 10 means very close." They reported separately on six groups: young White men/women, young Black men/women, and young Latino/a men/women. In general, there were no significant differences in reports of closeness for the men and women of each racial/ethnic group, thus they were 
averaged into one measure of closeness to each racial/ethnic group. Closeness to others is measured as the average of closeness to all racial/ethnic groups other than one's own.

Skin tone: Each interviewer was asked to give their "judgment as to the lightness or darkness of the respondent's skin color", on an 11-point scale that ranged from 0 (very light) to 10 (very dark). As expected the average skin tone rating was significantly different for each racial/ethnic group; mean of 4.95 for Black, 2.74 for Latino/a, and 1.69 for White students. There were no gender differences in average skin tone ratings. Skin tone was only significant for Black students, therefore only their ratings are detailed. In regression analyses, skin tone was examined as a linear and a nonlinear variable. To test for threshold effects, three dummy variables were created: (1) the lightest range of skin tones represented $24 \%$ of Black students, and ranged from 0 to 3 ; (2) the medium range of skin tones represented $48 \%$, and ranged from 4 to 6 ; (3) the darkest range of skin tones represented $28 \%$, and ranged from 7 to 10 . These skin tone ratings are subjective, and are unadjusted for the interviewer's race/ethnicity and gender.

Opportunity for intracultural segregation: Administrative report of the racial/ethnic composition of the college campus was used to create a variable indicating the percent of the student body that was of the same race/ethnicity as the student.

\subsubsection{Control Variables}

Several control measures were included, all reported in the fall of freshman year: (1) students' immigrant generational status, (2) whether a first generation college student, and (3) students' level of religiosity. All of these factors have been qualitatively and quantitatively associated with dating and endogamy [1]. Students were categorized as first immigrant generation if the student and at least one parent was foreign born; they were categorized as second immigrant generation if the student was born in the U.S. and at least one parent was foreign born; they were categorized as third or higher immigrant generation if the student and both parents were born in the U.S. There were too few first and second immigrant generation Black and White students, so they were collapsed into one category. There were no significant first versus second immigrant generation differences among Latino/a students. Immigrant generational status differed such that only $30 \%$ of Latino/a students were third or higher immigrant generation, compared to $72 \%$ of Black and $85 \%$ of White students. Students reported each parent's level of completed schooling, which was used to measure whether they were first generation college students. Religiosity is based on students' response to the following question: "On a scale of 0 to 10 , how religious would you say you are? Zero indicates you are extremely unreligious and 10 indicates you are extremely religious."

\subsection{Analytic Strategy}

Hierarchical linear modeling analyses were conducted to account for the nesting of students within each college [45]. Accounting for the nesting of students within institutions is particularly important given that the gender imbalance and racial/ethnic composition differs considerably between institutions. The first set of logit regression analyses focused on identifying the extent to which there are racial/ethnic differences in students' overall likelihood of intercultural dating. These analyses focused on determining the extent to which any observed racial/ethnic gaps were accounted for by the 
racial/ethnic diversity of students' friendship networks, and the level of diversity of the student body. The second set of regression analyses was limited to Black students, and focused on identifying the significance of skin color in their intercultural dating experiences.

For the regression analyses the following measures were standardized (grand mean centering): high school and college friendship network diversity, feelings of closeness to other groups, opportunity for intracultural segregation, and religiosity.

\section{Results}

\subsection{Racial/Ethnic and Gender Differences}

Table 1 shows that Latino/a students reported the highest likelihood of intercultural dating (90.7\%), next were Black students (54.2\%), and White students were the least likely (36.0\%). Comparing the bottom two panels of Table 1 shows that the gender gap in intercultural dating varies by racial/ethnic group. There was a large intercultural dating gender gap among Black students $(45.1 \%$ of women $v s$. $70.2 \%$ of men), and essentially no gender gap among White students (34.6\% of women $v s .37 .4 \%$ of men), and Latino/a students $(89.7 \%$ of women $v$ s. $92.0 \%$ of men). It is also important to note that intercultural relationships are lower among those in committed relationships. Among Latino/a students, $74.4 \%$ of the committed relationships were intercultural, 30.1\% among Black and $15.0 \%$ among White students.

Table 1. Group differences in romantic relationship experiences.

\begin{tabular}{|c|c|c|c|}
\hline & Black & Hispanic & White \\
\hline$\%$ That dated Interculturally ${ }^{a}$ & 54.17 & 90.66 & 36.02 \\
\hline$\%$ With no dates & 15.11 & 8.30 & 8.01 \\
\hline$\%$ In committed relationship & 47.12 & 54.15 & 52.39 \\
\hline$\%$ In committed intercultural relationship ${ }^{\mathrm{b}}$ & 30.95 & 75.67 & 15.07 \\
\hline $\mathrm{N}$ & 953 & 885 & 966 \\
\hline \multicolumn{4}{|l|}{ Women } \\
\hline$\%$ That dated Interculturally ${ }^{a}$ & 45.13 & 89.67 & 34.69 \\
\hline$\%$ With no dates & 15.04 & 9.36 & 9.26 \\
\hline$\%$ In committed relationship & 49.81 & 56.52 & 51.62 \\
\hline$\%$ In committed intercultural relationship ${ }^{b}$ & 24.91 & 74.90 & 12.56 \\
\hline $\mathrm{N}$ & 600 & 501 & 491 \\
\hline \multicolumn{4}{|l|}{ Men } \\
\hline$\%$ That dated Interculturally ${ }^{a}$ & 70.20 & 91.97 & 37.40 \\
\hline$\%$ With no dates & 15.23 & 6.85 & 6.68 \\
\hline$\%$ In committed relationship & 42.33 & 50.93 & 53.22 \\
\hline$\%$ In committed intercultural relationship ${ }^{b}$ & 43.65 & 76.83 & 17.67 \\
\hline $\mathrm{N}$ & 353 & 384 & 475 \\
\hline
\end{tabular}

Notes: ${ }^{\mathrm{a}}$ Among those who had at least 1 date; ${ }^{\mathrm{b}}$ Among those in a committed relationship. 


\subsection{Romantic Distance between Groups}

It was also important to explore the college-going romantic relationship distance between the various racial/ethnic groups (see Table 2). Black and Latino/a intercultural daters were most likely to have dated a White partner, but White daters were most likely to have dated an Asian partner. These differences were even larger when race/ethnicity and gender were combined. Among Black women who had dated interculturally, $77.5 \%$ had dated a White partner; however, among White men who had dated interculturally, only $23.7 \%$ had dated a Black partner. White women have the most balanced intercultural dating experiences; $52.7 \%$ reported dating an Asian partner, 44.5\% reported dating a Black partner, and $36.9 \%$ reported dating a Latino partner. In contrast, White men have the most skewed intercultural dating experiences; $76.3 \%$ reported dating an Asian partner, 36.8\% reported dating a Latina partner, and $23.7 \%$ reported dating a Black partner.

Table 2. Percent of intercultural daters that dated a member of given racial/ethnic group.

\begin{tabular}{llcccc}
\hline & \multicolumn{5}{c}{ Race/ethnicity of dating partner } \\
\hline \multirow{4}{*}{ Female Respondent } & & Black & Latino/a & White & Asian \\
& Black & -- & 46.95 & 77.46 & 26.29 \\
& Latino/a & 27.06 & -- & 90.98 & 19.63 \\
& White & 44.52 & 36.99 & -- & 52.74 \\
& Black & -- & 48.95 & 73.16 & 46.32 \\
Male Respondent & Latino/a & 18.71 & -- & 90.48 & 36.05 \\
& White & 23.68 & 36.84 & -- & 76.32 \\
\hline
\end{tabular}

\subsection{Accounting for Racial/Ethnic Gaps in Intercultural Dating}

The logistic regressions (see Table 3) show that the racial/ethnic diversity of students' high school friendship networks accounted for a significant amount of the racial/ethnic gaps in the likelihood of intercultural dating (Model 1 versus Model 2). Initially, Black students had 4.8 higher odds, and Latino/a students had 19.5 higher odds of intercultural dating, and after adding the high school friendship diversity Black students had 2.5 higher odds, and Latino/a students had 7.4 higher odds. Model 3 shows that accounting for the racial/ethnic diversity of students' freshman year friendship networks, and the opportunity for intracultural segregation (percent of undergraduate student body that is the same race/ethnicity as the student) further reduced the remaining racial/ethnic gaps in intercultural dating. After the freshman year variables were added, overall Black-White and Latino/ a-White gaps narrowed and became insignificant. This indicates that in addition to the diversity of one's immediate friendship network, as the diversity of the student body increases White students are more likely to enter into intercultural romantic relationships.

It is important to note that when friendship network diversity was added to the model the coefficient representing the interaction Black and female widened (Table 3, Model 1 versus Model 2) and remained significant in the final model. That for Black women the intercultural dating gap widens by accounting for friendship network diversity, indicates that Black women are significantly less likely to date interculturally than would be predicted given the diversity of their friendship network. Being in a diverse social network was not enough to fully overcome social distance barriers associated with dating. 
Table 3. Racial/ethnic gaps in intercultural dating, logistic regression.

\begin{tabular}{|c|c|c|c|}
\hline & Model 1 & Model 2 & Model 3 \\
\hline & $\begin{array}{l}\text { Odds Ratio } \\
\text { (Std. Err.) }\end{array}$ & $\begin{array}{l}\text { Odds Ratio } \\
\text { (Std. Err.) }\end{array}$ & $\begin{array}{l}\text { Odds Ratio } \\
\text { (Std. Err.) }\end{array}$ \\
\hline Black & $\begin{array}{l}4.83 * * * \\
(0.92)\end{array}$ & $\begin{array}{l}2.49 * * * \\
(0.51)\end{array}$ & $\begin{array}{l}0.80 \\
(0.39)\end{array}$ \\
\hline Latino/a & $\begin{array}{l}24.25 * * * \\
(6.59)\end{array}$ & $\begin{array}{l}7.43 * * * \\
(2.16)\end{array}$ & $\begin{array}{l}1.37 \\
(0.74)\end{array}$ \\
\hline Female & $\begin{array}{l}0.92 \\
(0.14)\end{array}$ & $\begin{array}{l}0.87 \\
(0.14)\end{array}$ & $\begin{array}{l}0.84 \\
(0.14)\end{array}$ \\
\hline Black X Female & $\begin{array}{l}0.35 * * * \\
(0.08)\end{array}$ & $\begin{array}{l}0.37 * * * \\
(0.09)\end{array}$ & $\begin{array}{l}0.41 * * * \\
(0.10)\end{array}$ \\
\hline Latino/a X Female & $\begin{array}{l}0.80 \\
(0.24)\end{array}$ & $\begin{array}{l}0.82 \\
(0.26)\end{array}$ & $\begin{array}{l}1.02 \\
(0.34)\end{array}$ \\
\hline Percent high school friends same race/ethnicity & & $\begin{array}{l}0.40 * * * \\
(0.03)\end{array}$ & $\begin{array}{l}0.51 \text { *** } \\
(0.04)\end{array}$ \\
\hline Percent freshman friends same race/ethnicity & & & $\begin{array}{l}0.54 * * * \\
(0.05)\end{array}$ \\
\hline Percent campus same race/ethnicity & & & $\begin{array}{l}0.63 * \\
(0.13)\end{array}$ \\
\hline Closeness to others & & & $\begin{array}{l}1.10 \\
(0.06)\end{array}$ \\
\hline First generation student & $\begin{array}{l}0.95 \\
(0.25)\end{array}$ & $\begin{array}{l}1.02 \\
(0.28)\end{array}$ & $\begin{array}{l}0.95 \\
(0.27)\end{array}$ \\
\hline First generation student X Black & $\begin{array}{l}0.71 \\
(0.22)\end{array}$ & $\begin{array}{l}0.90 \\
(0.30)\end{array}$ & $\begin{array}{l}0.92 \\
(0.32)\end{array}$ \\
\hline First generation student X Latino/a & $\begin{array}{l}0.43 * \\
(0.16)\end{array}$ & $\begin{array}{l}0.59 \\
(0.22)\end{array}$ & $\begin{array}{l}0.61 \\
(0.25)\end{array}$ \\
\hline Religiosity & $\begin{array}{l}0.92 \\
(0.05)\end{array}$ & $\begin{array}{l}0.94 \\
(0.05)\end{array}$ & $\begin{array}{l}0.96 \\
(0.05)\end{array}$ \\
\hline Third + Immigrant generation & $\begin{array}{l}0.81 \\
(0.10)\end{array}$ & $\begin{array}{l}0.87 \\
(0.12)\end{array}$ & $\begin{array}{l}0.87 \\
(0.12)\end{array}$ \\
\hline Constant & $\begin{array}{l}0.73 \\
(0.13)\end{array}$ & $\begin{array}{l}1.46 * \\
(0.26)\end{array}$ & $\begin{array}{l}3.96 * * * \\
(1.40)\end{array}$ \\
\hline
\end{tabular}

Notes: $* p<0.05, * * p<0.01, * * * p<0.0001$; Standard Error (Std. Err.) shown in parentheses.

\subsection{The Lingering Significance of Skin Tone}

The association between skin tone and relationship experiences was examined separately for each racial/ethnic group, and skin tone was only significant for Black students. Darker skin toned Black women and men were significantly less likely to have dated interculturally. Skin tone had a significant quadratic association with intercultural dating (Model 1, Table 4). To detail this quadratic association, we estimated the predicted probabilities for the likelihood of intercultural dating along the range of skin tones, with all other covariates set to their means (see Figure 1). Additional analyses showed that Black students in the middle of the skin tone distribution had 0.61 lower odds of intercultural dating 
compared to those in the lightest tercile of skin tone (results not shown in tables). Black students in the darkest tercile of the skin tone distribution had 0.40 lower odds of intercultural dating compared to those in the lightest tercile of skin tone.

Table 4. Association between skin tone and intercultural dating, logistic regression.

\begin{tabular}{lcc}
\hline & Model 1 & Model 2 \\
\hline & Odds Ratio & Odds Ratio \\
& (Std. Err.) & (Std. Err.) \\
\hline Skin tone & $0.64 * *$ & 0.85 \\
& 0.10 & $(0.15)$ \\
Skin tone squared & $1.03 *$ & 1.01 \\
& $(0.02)$ & $(0.02)$ \\
Percent high school friends same race/ethnicity & & $0.42 * * *$ \\
& & $(0.05)$ \\
Percent freshman friends same race/ethnicity & & $0.61 * * *$ \\
Percent campus same race/ethnicity & & $(0.07)$ \\
Female & & 1.37 \\
First generation student & $(1.66)$ \\
Religiosity & $0.31 * * *$ & $0.33 * * *$ \\
Third + Immigrant generation & $(0.05)$ & $(0.06)$ \\
& 0.70 & 0.94 \\
& $(0.13)$ & $(0.19)$ \\
& 0.98 & 1.01 \\
& $(0.06)$ & $(0.08)$ \\
& 0.68 & 0.96 \\
& & $(0.21)$ \\
& & $(6.40)$ \\
\hline
\end{tabular}

Notes: $* p<0.05, * * p<0.01,{ }^{* * *} p<0.001$; Standard Error (Std. Err.) shown in parentheses.

Figure 1. Association between skin tone and likelihood of intercultural dating.

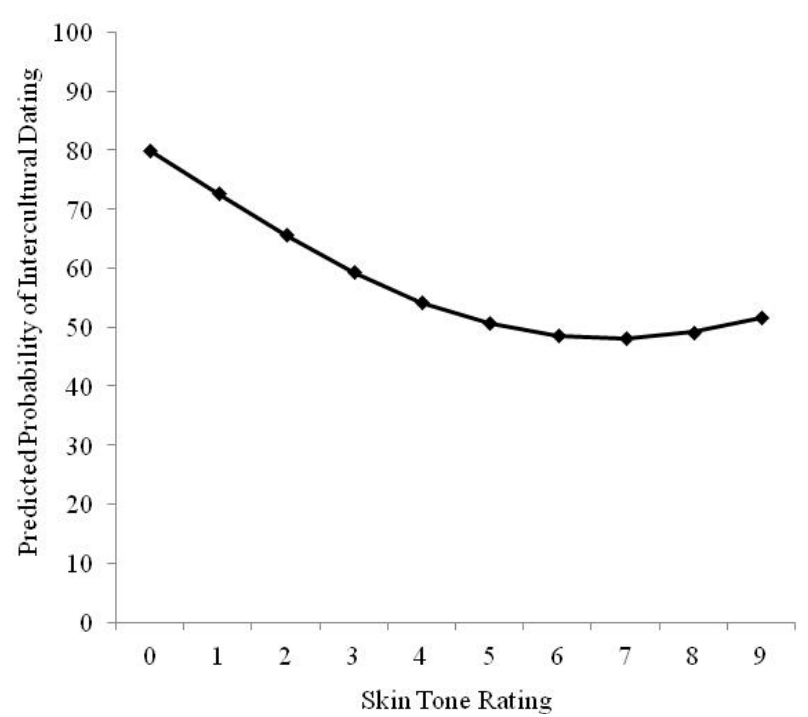

Note: Predicted probabilities are adjusted for all covariates shown in Table 4. 
The relationship between skin tone and intercultural dating was fully accounted for by adding friendship network diversity to the model (Model 2, Table 4). Essentially, darker skin toned Black students have significantly less diverse friendship networks, and as discussed in the introduction network diversity affects both opportunity and attitudes about intercultural dating.

\section{Discussion and Conclusions}

The primary objectives of this study were to examine the ways in which race/ethnicity-and-gender matter for college students' intercultural dating experiences, and to investigate whether the racial/ethnic preferences that are seen in American marriages are also observed among student's dating relationships. Race/ethnicity is a lived experience, and by thoughtfully examining our most personal social experiences, such as those with whom we choose to become romantically involved, claims of a post-racial America can be evaluated [46]. Among the current generation of college students attending PWIs, intercultural dating is a meaningful part of romantic life, with approximately $60 \%$ of students having engaged in at least one intercultural dating relationship by the end of their junior year. Furthermore, given the increasing diversity of college campuses, for all students, intercultural dating is positively associated with the likelihood of being in a dating or committed romantic relationship.

However, it appears that despite the diversity of today's college campuses, which are dramatically different than a generation ago, intercultural dating barriers surrounding Blacks, particularly Black women, are revealed to be stubbornly high. The racial/ethnic dating preferences of college students appear to reflect the general population of married Americans, the majority of whom did not experience the diverse college environments of today.

Our findings clearly show that friendship network diversity is an important precursor to intercultural dating, and that the diversity of both high school and college friendships matter. Universities are substantially more diverse than primary and secondary schools, but diversity alone does not guarantee the development of meaningful social relationships across racial/ethnic boundaries [40,47]. Much of the existing research finds that, on college campuses, micro-level segregation is high, and that White students have the most segregated friendship networks [40,48]. Proximal diversity appears to lead to significant improvements in Latino/a-White interpersonal relationships, but has little effect on Black-White interpersonal relationships [49]. Minority groups may self-segregate for identity and ego protection and majority groups may self-segregate because of comfort and demographic opportunity [40,50,51]. Intentional institutional action is necessary to better translate proximal diversity into social network diversity.

Demographic position on campus and access to the intercultural dating market combine to affect students overall dating experiences. As expected, because they are in a demographic position to do so, White students were the least likely to engage in intercultural dating; however, their low likelihood of intercultural dating does not affect their overall level of dating experiences. In contrast, the vast majority of Latino/a students engage in intercultural dating. Latinas, through high levels of intercultural dating are able to circumvent their within group campus gender imbalance, and date at levels similar to White women. In stark contrast, even though Black students are significantly more likely than White students to date interculturally, they have significantly fewer dating relationships than their same gender, White counterparts. 
Our finding that Black women are the least likely intercultural dating partner is not surprising, given that Black women are the furthest away from the light skin tone, sharp facial features, and long straight hair that are associated with mainstream U.S. standards of beauty [52]. These societal biases are reflected in online daters' declared physical preferences [53]. Furthermore, the U.S. has a long history of media portrayals of Black women as a combative relationship partner, which may limit non-Black men's willingness to initiate contact with Black women, even if physically attracted [54].

What does existing research tell us about why, after accounting for friendship network diversity, Black women have the lowest likelihood of intercultural dating? Research on online dating allows for an examination of who approaches and rejects whom during the dating process $[55,56]$. Online dating enables users to indicate the racial/ethnic preference of potential matches with little or no social consequences, thereby increasing the likelihood that these revealed preferences indicate true racial/ethnic preferences in dating. Additionally, when no racial/ethnic preferences are stated, preferences can be inferred from the likelihood of interacting with potential matches with various racial/ethnic characteristics. Focusing on the stated preferences of White men and Black women, Black women were more likely to include White men as possible matches than White men were to include them [55]. Next, the examination of behaviors (initiating contact, and responding or not to emails) show that online daters without stated racial/ethnic preferences exhibit racial/ethnic biases in their behaviors [56]. White men with no stated racial/ethnic preferences still act in accordance with societal biases, and infrequently initiate contact with or respond to contact initiated by Black women [57].

If Black women were to limit themselves to solely dating Black men, a significant number would have to forgo relationships altogether because of disproportionate Black male mortality and incarceration. Furthermore, because, on average, Black women have higher education levels than Black men, many would also have to choose a mate with significantly less education and earnings than themselves. Add to this Black women's increasing presence on college campuses and corporate workplaces, which disproportionately increases their contact with Whites, and reduces racial/ethnic barriers. These factors combine to push and pull them into the intercultural dating market, a market with limited potential suitors. As stated in the introduction, we are to know that a post-racial America has arrived once Americans become, if not color blind, at least matter-of-fact about color. These findings clearly show that the romantic lives of some of the most progressive Americans have yet to enter a post-racial Era. This is no clearer than in the significant negative associations between third party ratings of Black student's skin darkness and the likelihood of intercultural dating.

The results presented in this paper are limited by the lumping together of individuals who have had an intercultural relationship once or twice with those who do so regularly. Research shows that those who regularly have intercultural relationships are different from and have a different experience than those who have done so occasionally [38]. In addition, the skin tone analyses are limited by the subjectivity of the ratings, which has been shown to vary based on interviewer characteristics [58]. Skin tone is also only one aspect of phenotype, which limits our examination of the association between being stereotypically and prototypically Black, and dating experiences. Despite these limitations, the findings presented in this paper show that college students, particularly White men and women and Black women self select into or are restricted to a largely within race/ethnicity dating market.

It will be important for future research to examine within individual change in both intercultural friendships and dating over the course of college, to understand the extent to which change in one led 
to change in the other. Additionally, it will be important for future research to include a broader range of colleges and universities with regard to the racial/ethnic diversity of the student body and level of selectivity.

Reconciling America's color-blind ideals with continuing residential and romantic segregation is challenging. However, as research on residential segregation shows, small preferences have big effects [59]. It is not necessary for strong racist beliefs to underlie the fact that Black male-White female marriages are relatively rare, and that Black female-White male marriages are exceptionally rare. Romantic segregation is maintained by the ways in which America's history of race relations, continued social segregation, and concerns about social sanctioning maintain normative understandings of the deviance of various forms of intercultural intimacy.

\section{Acknowledgments}

This research was supported by a William T. Grant Scholars Program award granted to Micere Keels.

\section{Author Contributions}

Micere Keels performed the statistical analyses, and drafted parts of the manuscript; Keshia Harris drafted parts of the manuscript. Both authors read and approved the final manuscript.

\section{Conflicts of Interest}

The authors declare no conflict of interest.

\section{References}

1. Kalmijn, M. Intermarriage and homogamy: Causes, patterns, trends. Annu. Rev. Sociol. 1998, 24, $395-421$.

2. Qian, Z.; Lichter, D. Social boundaries and marital assimilation: Interpreting trends in racial and ethnic intermarriage. Am. Sociol. Rev. 2007, 72, 68-94.

3. Qian, Z. Race and social distance: Intermarriage with non-white Latinos. Race Soc. 2002, 5, $33-47$.

4. Gullickson, A. Education and black-white interracial marriage. Demography 2006, 43, 673-689.

5. Allport, G.W. The Nature of Prejudice; Addison-Wesley Pub. Co.: Cambridge, MA, USA, 1954; p. 537.

6. Gordon, M.M. Assimilation in American Life: The Role of Race, Religion, and National Origins; Oxford University Press: New York, NY, USA, 1964; p. 276.

7. Bowman, N.; Denson, N. What's past is prologue: How precollege exposure to racial diversity shapes the impact of college interracial interactions. Res. High. Educ. 2012, 53, 406-425.

8. Schoepflin, T. Perspectives of interracial dating at a predominantly white university. Sociol. Spectr. 2009, 29, 346-370.

9. Stearns, E.; Buchmann, C.; Bonneau, K. Interracial friendships in the transition to college: Do birds of a feather flock together once they leave the nest? Sociol. Educ. 2009, 82, 173-195.

10. Hunter, M. The persistent problem of colorism: Skin tone, status, and inequality. Sociol. Compass 2007, 1, 237-254. 
11. Glenn, E. Yearning for lightness: Transnational circuits in the marketing and consumption of skin lighteners. Gender Soc. 2008, 22, 281-302.

12. Yancey, G. Crossracial differences in the racial preferences of potential dating partners: A test of the alienation of African Americans and social dominance orientation. Sociol. Quart. 2009, 50, 121-143.

13. Passel, J. S.; Wang, W.; Taylor, P. Marrying out: One-in-seven new U.S. marriages is interracial or interethnic. Available Online: http://pewresearch.org/pubs/1616/american-marriage-interracialinterethnic (accessed on 15 January 2014).

14. Wilkins, C.; Chan, J.; Kaiser, C. Racial stereotypes and interracial attraction: Phenotypic prototypicality and perceived attractiveness of Asians. Cult. Divers. Ethnic Minor. Psychol. 2011, 17, 427-431.

15. Shook, N.; Fazio, R. Interracial roommate relationships-An experimental field test of the contact hypothesis. Psychol. Sci. 2008, 19, 717-723.

16. Lee, J.; Bean, F. Redrawing the color line? City Community 2007, 6, 49-62.

17. Crowder, K.; Tolnay, S. A new marriage squeeze for black women: The role of racial intermarriage by black men. J. Marriage Fam. 2000, 62, 792-807.

18. Snyder, T.D.; Dillow, S.A. Digest of Educational Statistics; National Center for Education Statistics, Institute of Education Sciences, U.S. Department of Education: Washington, DC, USA, 2010. Available online: http://nces.ed.gov/pubs2011/2011015.pdf (accessed on 15 January 2014).

19. Chapman, A.B. Man Sharing: Dilemma of Choice, a Radical New Way of Relating to the Men in Your Life; William Morrow \& Co.: New York, NY, USA, 1986.

20. Staples, R. Race and marital status: An overview. In Black Families; McAdoo, H.P., Ed. Sage: Thousand Oaks, CA, USA, 1981; pp. 187-189.

21. Alleyne, B.; Gaston, G. Gender disparity and HIV risk among young black women in college: A literature review. Affilia. J. Women Soc. Work 2010, 25, 135-145.

22. Braithwaite, S.; Delevi, R.; Fincham, F. Romantic relationships and the physical and mental health of college students. Pers. Relatsh. 2010, 17, 1-12.

23. Furman, W.; Buhrmester, D. Age and sex-differences in perceptions of networks of personal relationships. Child Dev. 1992, 63, 103-115.

24. McClintock, E. When does race matter? Race, sex, and dating at an elite university. J. Marriage Fam. 2010, 72, 45-72.

25. Joyner, K.; Kao, G. Interracial relationships and the transition to adulthood. Am. Sociol. Rev. 2005, 70, 563-581.

26. Levin, S.; Taylor, P.; Caudle, E. Interethnic and interracial dating in college: A longitudinal study. J. Soc. Pers. Relatsh. 2007, 24, 323-341.

27. Raley, R.; Sullivan, M. Social-contextual influences on adolescent romantic involvement: The constraints of being a numerical minority. Sociol. Spectr. 2010, 30, 65-89.

28. Fiebert, M.; Karamol, H. Interracial dating: Attitudes and experience among American college students in California. Psychol. Rep. 2000, 87, 1059-1064.

29. Tsunokai, G.T.; Kposowa, A.J.; Adams, M.A. Racial preferences in internet dating: A comparison of four birth cohorts. West. J. Black. Stud. 2009, 33, 1-15. 
30. Saenz, V.B.; Ponjuan, L. The vanishing Latino male in higher education. J. Hispan. High. Educ. 2009, 8, 35 .

31. Qian, Z.; Cobas, J. Latinos' mate selection: National origin, racial, and nativity differences. Soc. Sci. Res. 2004, 33, 225-247.

32. Stephens, D.; Fernandez, P.; Richman, E. Ni pardo, ni prieto: The influence of parental skin color messaging on heterosexual emerging adult white-Hispanic women's dating beliefs. Women Ther. 2012, 35, 4-18.

33. Nesteruk, O.; Gramescu, A. Dating and mate selection among young adults from immigrant families. Marriage Fam. Rev. 2012, 48, 40-58.

34. Moran, R.F. Interracial Intimacy: The Regulation of Race \& Romance; University of Chicago Press: Chicago, IL, USA, 2001.

35. Firmin, M.W.; Firebaugh, S. Historical analysis of college campus interracial dating. Coll. Student J. 2008, 42, 782-788.

36. Knox, D.; Zusman, M.E.; Buffington, C.; Hemphill, G. Interracial dating attitudes among college students. Coll. Student J. 2000, 34, 69-71.

37. Clark-Ibanez, M.; Felmlee, D. Interethnic relationships: The role of social network diversity. J. Marriage Fam. 2004, 66, 293-305.

38. Herman, M.; Campbell, M. I wouldn't, but you can: Attitudes toward interracial relationships. Soc. Sci. Res. 2012, 41, 343-358.

39. Pettigrew, T.; Tropp, L. A meta-analytic test of intergroup contact theory. J. Pers. Soc. Psychol. 2006, 90, 751-783.

40. Fischer, M. Does campus diversity promote friendship diversity? A look at interracial friendships in college. Soc. Sci. Quart. 2008, 89, 631-655.

41. Saenz, V.; Ngai, H.; Hurtado, S. Factors influencing positive interactions across race for African American, Asian American, Latino, and white college students. Res. High. Educ. 2007, 48, 1-38.

42. Hill, M. Skin color and the perception of attractiveness among African Americans: Does gender make a difference? Soc. Psychol. Quart. 2002, 65, 77-91.

43. Lee, S.S. Love sees no color or boundaries? Interethnic dating and marriage patterns of Dominican and CEP (Columbian, Ecuadorian, and Peruvian) Americans. J. Lat. Am. Stud. 2006, 2, 84-102.

44. Massey, D.S. The Source of the River: The Social Origins of Freshmen at America's Selective Colleges and Universities; Princeton University Press: Princeton, NJ, USA, 2003.

45. Raudenbush, S.W.; Bryk, A.S. Hierarchical Linear Models: Applications and Data Analysis Methods, 2nd ed.; Sage Publications: Thousand Oaks, CA, USA, 2002.

46. Warmington, P. Taking race out of scare quotes: Race-conscious social analysis in an ostensibly post-racial world. Race Ethnic. Educ. 2009, 12, 281-296.

47. Pike, G.R.; Kuh, G.D. Relationships among structural diversity, informal peer interactions and perceptions of the campus environment. Rev. High. Educ. 2006, 29, 425-450.

48. Odell, P.; Korgen, K.; Wang, G. Cross-racial friendships and social distance between racial groups on a college campus. Innov. High. Educ. 2005, 29, 291-305.

49. Dixon, J.C. The ties that bind and those that don't: Toward reconciling group threat and contact theories of prejudice. Soc. Forces 2006, 84, 2179-2204. 
50. Levin, S.; Van Laar, C.; Foote, W. Ethnic Segregation and Perceived Discrimination in College: Mutual Influences and Effects on Social and Academic Life. J. Appl. Soc. Psychol. 2006, 36, 1471-1501.

51. Villalpando, O. Self-segregation or self-preservation? A critical race theory and Latina/o critical theory analysis of a study of Chicana/o college students. Qual. Stud. Educ. 2003, 16, 619-646.

52. Craig, M.L. Ain't I a Beauty Queen?: Black Women, Beauty, and the Politics of Culture; Oxford University Press: New York, NY, USA, 2002.

53. Glasser, C.; Robnett, B.; Feliciano, C. Internet daters' body type preferences: Race-ethnic and gender differences. Sex Roles 2009, 61, 14-33.

54. Entman, R.M.; Rojecki, A. The Black Image in the White Mind: Media and Race in America; University of Chicago Press: Chicago, IL, USA, 2000.

55. Feliciano, C.; Robnett, B.; Komaie, G. Gendered racial exclusion among white internet daters. Soc. Sci. Res. 2009, 38, 41-56.

56. Hitsch, G.J.; Hortacsu, A.; Ariley, D. What makes you click: An empirical analysis of online dating. Available online: http://home.uchicago.edu/ ghitsch/Hitsch-Research/Guenter_Hitsch_files/ Mate-Preferences.pdf (accessed on 15 January 2014).

57. Rudder, C. How your race affects the messages you get. Ok Trends Weblog. Available online: http://blog.okcupid.com/index.php/your-race-affects-whether-people-write-you-back (accessed on 15 January 2014).

58. Lopez, I. "But you don't look Puerto Rican": The moderating effect of ethnic identity on the relation between skin color and self-esteem among Puerto Rican women. Cult. Divers. Ethnic Min. Psychol. 2008, 14, 102-108.

59. Fossett, M. Ethnic preferences, social distance dynamics, and residential segregation: Theoretical explorations using simulation analysis. J. Math. Sociol. 2006, 30, 185-273.

(C) 2014 by the authors; licensee MDPI, Basel, Switzerland. This article is an open access article distributed under the terms and conditions of the Creative Commons Attribution license (http://creativecommons.org/licenses/by/3.0/). 